\title{
ARTICLE
}

\section{Radiation impact of very low level radioactive steel reused in motorway tunnel constructions}

\author{
Tomas Hrncir ${ }^{*}$ and Vladimir Necas \\ Slovak University of Technology in Bratislava, Ilkovicova 3, 812 19, Bratislava, Slovak Republic
}

\begin{abstract}
Considerable amount of radioactive materials arising from decommissioning of nuclear power plants may be classified as very low level radioactive waste. Various types of mentioned radioactive materials were analyzed in several international documents devoted to the optimization of radioactive material management with emphasis on concepts of recycling and reuse. One of these concepts of optimization is the conditional clearance of materials with their subsequent recycling and reuse in industrial sector. The concept of conditional clearance of radioactive materials into the environment follows international recommendations derived from the principles that the individual effective dose received by critical individual must not exceed some tens of $\mu \mathrm{Sv} / \mathrm{yr}$. This paper deals with the radiation impact of recycling and reuse of conditionally cleared steel in industrial sector, specifically in motorway tunnel constructions. Scenario of the reuse of radioactive steel in form of reinforcing mesh and bars was created based on the data acquired from current motorway building practice in the Slovak Republic. The aim of the paper is to assess the radiation impact and to justify new specific clearance levels for radionuclides contained in steel reinforcement components in order to clear and reuse maximum amount of very low level radioactive steel considering mentioned dose criterion.
\end{abstract}

Keywords: conditional clearance; decommissioning; dose rates; exposure pathways; clearance levels; VISIPLAN 3D ALARA; GOLDSIM

\section{Introduction}

Nowadays, management of radioactive waste represents a world-wide discussed topic. There exist international incentives to minimize amount of radioactive waste using various concepts of clearance. Dose criteria applied for the clearance of radioactive materials was determined in order to ensure the protection to the public from radiation exposure. Conditional clearance represents alternative approach that also meets these health protection limits. In general, this alternative approach may lead to higher clearance limits compared to unconditional clearance while the protection of public is being achieved at the same level [1]. The concept of conditional clearance includes following requirements:

- Mainly solid metal radioactive materials are taken into account.

- Materials contain mostly relatively short-lived radionuclides.

- Long-term fixing of short-lived radionuclides in specific, previously defined, industrial constructions is required (this ensures significant reduction of radioactivity and possible detrimental impacts).

- Dose criteria (DC) of individual effective dose of

*Corresponding author. Email: tomas.hrncir@stuba.sk some tens of $\mu \mathrm{Sv} / \mathrm{year}$ and collective effective dose of 1 man Sv/year based on international recommendation $[2,3]$.

However, current legislation of the Slovak Republic (Statutory Order No. 345/2006 Coll.) stipulates the constraint of individual effective dose as $10 \mu \mathrm{Sv} /$ year or $50 \mu \mathrm{Sv} /$ year considering specific conditions.

\section{Motorway tunnel scenario}

\subsection{Basic information}

Motorway tunnel scenario is based on the data on real tunnel construction comprising two tunnel tubes, which will carry the unidirectional traffic during a standard operation. The total lengths of the modeled tunnel tubes are $2 \mathrm{~km}$. This length is chosen because it represents approximately the average length of existing tunnel constructions in the Slovak Republic. The reinforcement of the tunnel consists of primary and secondary lining. Following two possibilities were indentified based on specific analysis of optimal reuse of reinforcing components made from very low level (VLL) radioactive steel:

- Bars bound together in reinforcement cage of the strip foundation in secondary lining.

- Two layers of steel reinforcing mesh in primary lining. 


\begin{tabular}{|c|c|c|c|}
\hline $\begin{array}{l}\text { Melting and Reinforcing } \\
\text { Components Production }\end{array}$ & W - Worker & M - Member of the Public & Long-term Period \\
\hline \multirow[t]{2}{*}{ Inhalation - W } & Motorway Tunnel Building Stage & Motorway Tunnel Operation Stage & Inhalation - M \\
\hline & \multicolumn{2}{|c|}{ I } & \\
\hline Ingestion - W & \multirow{3}{*}{ No internal exposure is assumed } & \multirow{3}{*}{ No internal exposure is assumed } & Ingestion - M \\
\hline & & & \\
\hline Skin Contamination - W & & & Skin Contamination - M \\
\hline External Exposure - W & External Exposure - W & External Exposure - W, M & External Exposure - M \\
\hline $\mathrm{T}_{0}=0$ years & 3 years & 100 years & 10000 years \\
\hline
\end{tabular}

Figure 1. Scheme of exposure pathways relevant for motorway tunnel scenario

\subsection{Methodology}

The impact assessment methodology of the reuse of very low level radioactive steel in form of reinforcement mesh and bars, which partially arises out of the international methodology for the application of the concepts of exclusion, exemption and clearance [2,3] comprises following steps:

1. Determination of nuclide vector composition contained in conditionally cleared metals.

2. Definition of set of tunnel construction parameters and related performed activities.

3. Development of geometrical, radiological and material model of selected enveloping scenarios.

4. Calculation of received annual individual effective doses for each relevant exposure pathway.

5. Identification of the critical individual in limiting enveloping scenario for each set of calculations.

6. Derivation of new clearance levels for limiting scenario for each considered radionuclide.

The last step of analysis is represented by calculation of amount of radioactive metal materials arising from decommissioning of given NPP that can be conditionally cleared and reused safely in motorway tunnel.

\subsection{Relevant exposure pathways}

Radiological impact analysis was divided into following four stages (four timescales were considered):

- Melting of metal radioactive material and production of reinforcing components in controlled area (3 years).

- Building of motorway tunnel (3 years).

- Operation of motorway tunnel (100 years).

- Long-term radiological impacts (10 000 years).

Exposure pathways (EP) such as inhalation, ingestion and skin contamination are considered in case of radionuclides occurrence in dust, water or food causing possible intake of these radionuclides by workers or members of the public. Radionuclides may be generated in the form of dust or aerosols also during some specific thermal processes such as melting, welding or using cutting torch. Based on the data from current industrial practice, no thermal processes are used during building of motorway tunnel and operational stage, therefore no internal exposure is assumed due to negligible level of dust/aerosols generation.

Relevant exposure pathways identified for the motorway tunnel scenario are depicted on Figure 1. In general, four exposure pathways were indentified: external exposure (EXT), inhalation (INH), ingestion (ING) and skin contamination (SKIN).

\subsection{Radiological impact assessment}

\subsubsection{Analyzed nuclide vector}

Table 1 includes selected radionuclides analyzed in dose assessment based on radiological characterization of A1 NPP located in the Slovak Republic.

Table 1. List of radionuclides considered in assessment

\begin{tabular}{cc}
\hline Exposure pathway & Considered radionuclides \\
\hline External Exposure (EXT) & ${ }^{60} \mathrm{Co},{ }^{94} \mathrm{Nb},{ }^{126} \mathrm{Sn},{ }^{137} \mathrm{Cs},{ }^{152} \mathrm{Eu}$, \\
\hline Inhalation (INH) & ${ }^{239} \mathrm{Pu}$ \\
Ingestion (ING) & ${ }^{3} \mathrm{H},{ }^{59} \mathrm{Mo},{ }^{93} \mathrm{Zr},{ }^{60} \mathrm{Co},{ }^{63} \mathrm{Nb},{ }^{99} \mathrm{Tc},{ }^{90} \mathrm{Sr}$, \\
Skin Contamination (SKIN) & ${ }^{129} \mathrm{I},{ }^{137} \mathrm{Cs},{ }^{151} \mathrm{Sm},{ }^{152} \mathrm{Eu},{ }^{238} \mathrm{Pu}$, \\
\hline
\end{tabular}

Sets of radionuclides considered in particular exposure pathways differ due to natural behavior of particular radionuclides (i.e. only gamma radiation emitters are considered in external exposure pathway).

\subsubsection{Results}

Assessment of possible exposure pathways relevant for melting, construction, operation and long-term period was performed. Internal exposure and skin contamination of workers conducting activities related to the melting stage was performed based on equations, parameters and approaches applied in international recommendations [3]. The computational tool VISIPLAN 3D ALARA was used for calculation of external individual effective doses [4]. The simulation software GOLDSIM was used for the assessment of long-term impacts. GOLDSIM environment enables modeling of degradation processes and transport of radionuclides through unsaturated and saturated zone of subsoil [5]. 
Table 2. Results of radiation impact assessment for radionuclide ${ }^{60} \mathrm{Co}$

\begin{tabular}{|c|c|c|c|c|}
\hline Stage & $\begin{array}{l}\text { Performed activity / enveloping } \\
\text { scenario }\end{array}$ & $\begin{array}{l}\text { Annual exposure } \\
\text { time (hours) }\end{array}$ & $\begin{array}{l}\text { Annual received } \\
\text { individual effective } \\
\text { dose }(\mu S v)\end{array}$ & $\begin{array}{c}\text { Specific mass activity } \\
\text { contained in metal material } \\
(\mathrm{Bq} / \mathrm{kg})\end{array}$ \\
\hline \multirow{6}{*}{$\begin{array}{c}\text { Melting and } \\
\text { Reinforcing } \\
\text { Components } \\
\text { Production Stage }\end{array}$} & Cutting and manipulation & 1100 & 33.17 & 301.5 \\
\hline & Melting and slag handling & 715 & 4.91 & 301.5 \\
\hline & Storage of ingots/reinforcing components & 220 & 5.02 & 300 \\
\hline & Manufacture of reinforcing components & 770 & 1.28 & 300 \\
\hline & Manipulation of manufactured re-bars & 660 & 3.74 & 300 \\
\hline & Transport of reinforcing components & 150 & 1.50 & 300 \\
\hline \multirow{4}{*}{ Building Stage } & Assembly of primary lining (PL) & 1925 & 6.17 & 300 \\
\hline & Assembly of strip foundation & 550 & 2.55 & 300 \\
\hline & Realization of secondary lining & 840 & 2.31 & 300 \\
\hline & Storage of steel mesh and re-bars & 58 & 2.39 & 300 \\
\hline \multirow{3}{*}{ Operation Stage } & Maintenance of already built tunnel & 130 & 9.53E-03 & 300 \\
\hline & Professional driver & 50 & $5.20 \mathrm{E}-03$ & 300 \\
\hline & Driver or passenger & 10 & $1.04 \mathrm{E}-03$ & 300 \\
\hline Long-term Period & Inhabitant with garden & 8760 (whole year) & 1.13E-08 & 300 \\
\hline
\end{tabular}

Parameters related to impact assessment were acquired from tunnel construction experts, international documents published by IAEA or European Commission [3,6] and reports dealing with dose assessment of workers during melting process.

Radiation impact assessment of last 3 stages considers specific mass activity $300 \mathrm{~Bq} / \mathrm{kg}$ contained in material.

In case of melting stage, it is necessary to bear in mind distribution of radioactivity during melting process [7]. Therefore specific mass activity of metal components before melting was recalculated using distribution coefficients. Furthermore, it is assumed that melting and reinforcing components production would take a place in controlled area. Therefore dose limit of $20 \mathrm{mSv} /$ year is relevant for this stage.

Table 2 contains example of calculated individual effective doses received by workers or members of public performing analyzed activities.

The same calculations were performed for each analyzed radionuclide. Aim of the assessment is to identify critical individual or limiting enveloping scenario (ES) respectively.

\subsection{Clearance levels}

The derivation of the new clearance levels (CL) is performed by following formula ensuring that radiation protection criteria will be met:

$$
A=\frac{D_{C}}{I E D} A_{u}
$$

Where:

A - Specific activity concentration of radionuclide (clearance level),

$\mathrm{D}_{\mathrm{C}} \quad$ - Dose criterion (10 $\mu \mathrm{Sv} /$ year or $50 \mu \mathrm{Sv} /$ year $)$,

IED - Calculated annual individual effective dose received by individual in limiting scenario,
$A_{u} \quad-$ Reference value of specific mass activity.

Derived values of new clearance levels can be seen in Table 3 and Table 4 along with limiting enveloping scenario and exposure pathway. Tables also include limit value of specific mass activity for unconditional clearance (UC) defined in Slovak legislation.

Derived clearance levels of few radionuclides $\left({ }^{129} \mathrm{I}\right.$ and ${ }^{93} \mathrm{Zr}$ ) are even lower than UC limit values. This fact can be caused by undue level of conservatism applied in assessment of melting stage, which could lead to overestimating of received doses. Furthermore no measures for restriction of internal exposure during melting stage were considered.

Table 3. Derived CL considering $10 \mu \mathrm{Sv} /$ year dose criterion

\begin{tabular}{|c|c|c|c|c|}
\hline Nuclide & $\begin{array}{c}\text { UC limit } \\
\text { value }(\mathrm{Bq} / \mathrm{kg})\end{array}$ & $\begin{array}{c}\text { Derived CL } \\
\text { (Bq/kg) }\end{array}$ & Limiting ES & $\begin{array}{c}\text { Limiting } \\
\text { EP }\end{array}$ \\
\hline${ }^{3} \mathrm{H}$ & $3,00 \mathrm{E}+06$ & $1,80 \mathrm{E}+09$ & Melting & ING \\
\hline${ }^{59} \mathrm{Ni}$ & $3,00 E+05$ & $1,10 \mathrm{E}+08$ & Inhabitant & ING \\
\hline${ }^{60} \mathrm{Co}$ & $3,00 \mathrm{E}+02$ & $4,80 \mathrm{E}+02$ & Assembly of PL & EXT \\
\hline${ }^{63} \mathrm{Ni}$ & $3,00 \mathrm{E}+06$ & $2,90 \mathrm{E}+08$ & Inhabitant & ING \\
\hline${ }^{90} \mathrm{Sr}$ & $3,00 E+03$ & $1,40 E+05$ & $\begin{array}{l}\text { Cutting and } \\
\text { Manipulation }\end{array}$ & SKIN \\
\hline${ }^{93} \mathrm{Mo}$ & $3,00 \mathrm{E}+04$ & $6,90 \mathrm{E}+06$ & Inhabitant & ING \\
\hline${ }^{93} \mathrm{Zr}$ & $3,00 \mathrm{E}+05$ & $6,00 \mathrm{E}+04$ & Melting & INH \\
\hline${ }^{94} \mathrm{Nb}$ & $3,00 E+02$ & $6,50 \mathrm{E}+02$ & Assembly of PL & EXT \\
\hline${ }^{99} \mathrm{Tc}$ & $3,00 \mathrm{E}+05$ & $1,90 \mathrm{E}+07$ & Inhabitant & ING \\
\hline${ }^{126} \mathrm{Sn}$ & $3,00 E+03$ & $2,10 \mathrm{E}+04$ & Assembly of PL & EXT \\
\hline${ }^{129} \mathrm{I}$ & $3,00 \mathrm{E}+04$ & $1,10 \mathrm{E}+04$ & Melting & ING \\
\hline${ }^{137} \mathrm{Cs}$ & $3,00 \mathrm{E}+02$ & $1,80 \mathrm{E}+03$ & Assembly of PL & EXT \\
\hline${ }^{151} \mathrm{Sm}$ & $3,00 \mathrm{E}+05$ & $1,10 \mathrm{E}+07$ & Melting & INH \\
\hline${ }^{152} \mathrm{Eu}$ & $3,00 \mathrm{E}+02$ & $9,80 \mathrm{E}+02$ & Assembly of PL & EXT \\
\hline${ }^{238} \mathrm{Pu}$ & $3,00 \mathrm{E}+02$ & $3,90 \mathrm{E}+03$ & Melting & INH \\
\hline${ }^{239} \mathrm{Pu}$ & $3,00 \mathrm{E}+02$ & $9,80 \mathrm{E}+02$ & Melting & INH \\
\hline${ }^{241} \mathrm{Am}$ & $3,00 \mathrm{E}+02$ & $1,20 \mathrm{E}+03$ & Melting & INH \\
\hline
\end{tabular}


Table 4. Derived CL considering $50 \mu \mathrm{Sv} / \mathrm{year}$ dose criterion

\begin{tabular}{|c|c|c|c|c|}
\hline Nuclide & $\begin{array}{c}\text { UC limit } \\
\text { value }(\mathrm{Bq} / \mathrm{kg})\end{array}$ & $\begin{array}{l}\text { Derived CL } \\
(\mathrm{Bq} / \mathrm{kg})\end{array}$ & Limiting ES & $\begin{array}{l}\text { Limiting } \\
\text { EP }\end{array}$ \\
\hline${ }^{3} \mathrm{H}$ & $3,00 \mathrm{E}+06$ & $1,80 \mathrm{E}+09$ & Melting & ING \\
\hline${ }^{59} \mathrm{Ni}$ & $3,00 E+05$ & $5,50 \mathrm{E}+08$ & Inhabitant & ING \\
\hline${ }^{60} \mathrm{Co}$ & $3,00 \mathrm{E}+02$ & $2,40 E+03$ & Assembly of PL & EXT \\
\hline${ }^{63} \mathrm{Ni}$ & $3,00 \mathrm{E}+06$ & $1,50 \mathrm{E}+09$ & Inhabitant & ING \\
\hline${ }^{90} \mathrm{Sr}$ & $3,00 \mathrm{E}+03$ & $1,44 \mathrm{E}+05$ & $\begin{array}{l}\text { Cutting and } \\
\text { Manipulation }\end{array}$ & SKIN \\
\hline${ }^{93} \mathrm{Mo}$ & $3,00 \mathrm{E}+04$ & $3,50 \mathrm{E}+07$ & Inhabitant & ING \\
\hline${ }^{93} \mathrm{Zr}$ & $3,00 \mathrm{E}+05$ & $6,00 \mathrm{E}+04$ & Melting & INH \\
\hline${ }^{94} \mathrm{Nb}$ & $3,00 \mathrm{E}+02$ & $7,70 \mathrm{E}+02$ & $\begin{array}{l}\text { Cutting and } \\
\text { Manipulation }\end{array}$ & EXT \\
\hline${ }^{99} \mathrm{Tc}$ & $3,00 \mathrm{E}+05$ & $9,80 \mathrm{E}+07$ & Inhabitant & ING \\
\hline${ }^{126} \mathrm{Sn}$ & $3,00 E+03$ & $1,10 \mathrm{E}+05$ & Assembly of PL & EXT \\
\hline${ }^{129} \mathrm{I}$ & $3,00 \mathrm{E}+04$ & $1,08 \mathrm{E}+04$ & Melting & ING \\
\hline${ }^{137} \mathrm{Cs}$ & $3,00 \mathrm{E}+02$ & $2,10 \mathrm{E}+03$ & $\begin{array}{l}\text { Cutting and } \\
\text { Manipulation }\end{array}$ & EXT \\
\hline${ }^{151} \mathrm{Sm}$ & $3,00 E+05$ & $1,08 \mathrm{E}+07$ & Melting & INH \\
\hline${ }^{152} \mathrm{Eu}$ & $3,00 E+02$ & $1,20 E+03$ & $\begin{array}{l}\text { Cutting and } \\
\text { Manipulation }\end{array}$ & EXT \\
\hline${ }^{238} \mathrm{Pu}$ & $3,00 E+02$ & $3,88 \mathrm{E}+03$ & Melting & INH \\
\hline${ }^{239} \mathrm{Pu}$ & $3,00 E+02$ & $9,80 \mathrm{E}+02$ & Melting & INH \\
\hline${ }^{241} \mathrm{Am}$ & $3,00 \mathrm{E}+02$ & $1,18 \mathrm{E}+03$ & Melting & INH \\
\hline
\end{tabular}

Generally, derived clearance levels for majority of radionuclides could be at least one order of magnitude higher than values given in Slovak legislation for unconditional clearance.

\subsection{Amount of recyclable radioactive steel}

Calculation of recyclable amount of steel was performed using OMEGA code and comprehensive database of A1 NPP components and technological equipment. This code enables to determine various parameters related to decommissioning [8].

Since, practically all metal components arising from decommissioning of NPP contained mixture of radionuclides, following formula was used in order to meet clearance limits [3,6]:

$$
\sum_{\mathrm{i}=1}^{\mathrm{n}} \frac{\mathrm{A}_{\mathrm{i}}}{\mathrm{Au}_{\mathrm{i}}}<1
$$

Where:

$\mathrm{A}_{\mathrm{i}}-$ Specific mass activity of $\mathrm{i}^{\text {th }}$ radionuclide contained in material,

$\mathrm{Au}_{\mathrm{i}}$ - Clearance level value of $\mathrm{i}^{\text {th }}$ radionuclide contained in material.

Table 5 comprises calculated amount of different types of steel arising from decommissioning of A1 NPP that can be recycled and reused in motorway tunnel construction analyzed in paper. Results obtained from performed analysis indicates that concept of conditional clearance could significantly increase amount of recyclable steel and save disposal capacity. However it would be appropriate to conduct further analyses in order to decrease undue level of conservatism and to optimize the process of reuse of VLL radioactive steel.
Table 5. Calculated amount of recyclable steel (RS) arising from decommissioning of A1 NPP

\begin{tabular}{ccc}
\hline Type of Steel & $\begin{array}{c}\text { Amount of RS } \\
10 \mu \mathrm{Sv} / \text { year DC } \\
(\mathrm{kg})\end{array}$ & $\begin{array}{c}\text { Amount of RS } \\
50 \mu \mathrm{Sv} / \text { year DC } \\
(\mathrm{kg})\end{array}$ \\
\hline Carbon steel & 112622.96 & 1045307.57 \\
Stainless steel & 2166.60 & 2166.60 \\
\hline Total & 114789.56 & 1047474.17 \\
\hline
\end{tabular}

\section{Conclusion}

To conclude, assessment results indicates that implementation of the concept of conditional clearance may lead to saving of considerable financial resources, which would be otherwise used for treatment, conditioning and disposal of very low level radioactive steel. Furthermore it could save valuable materials itself (particularly metals), which can be recycled and reused safely in motorway tunnel constructions.

Anyway, prior to real application of this alternative approach, it will be essential to discuss mentioned issue with all relevant stakeholders (e.g. industry, government, members of the public) and to define legal framework.

\section{Acknowledgements}

This project has been partially supported by the Slovak Grant Agency for Science through the grant No. VEGA 1/0685/09, VEGA 1/0796/13 and by the Ministry of Education by decree No. CD-2009-36909/39460-1:11 within the bounds of project CONRELMAT.

\section{References}

[1] International Atomic Energy Agency, Managing Low Radioactivity Material from the Decommissioning of Nuclear Facilities, (2008).

[2] International Atomic Energy Agency, Application of the Concepts of Exclusion, Exemption and Clearance, (2004).

[3] International Atomic Energy Agency, Derivation of Activity Concentrations Values for Exclusion, Exemption and Clearance, (2005).

[4] F. Vermeersch, VISIPLAN 3D ALARA Planning Tool, User's Guide, (2005).

[5] GoldSim Technology Group, GoldSim, User's Guide, (2010).

[6] European Commission, Practical Use of the Concepts of Clearance and Exemption, Radiation protection 122, (2000).

[7] U.S. Nuclear Regulatory Commission, Radiological Assessment for Clearance of Materials from Nuclear Facilities, NUREG-1640, (2003).

[8] M. Zachar, V. Daniska and V. Necas, Improved analytical methodology for calculation assessment of material parameters in the nuclear installation decommissioning process, Progress in Nuclear Energy 53 (2011), pp. 463-470. 